Research article

\title{
Methylation of homeobox genes is a frequent and early epigenetic event in breast cancer
}

\author{
Stella Tommasi ${ }^{1}$, Deborah L Karm ${ }^{1}$, Xiwei Wu ${ }^{2}$, Yun Yen ${ }^{3}$ and Gerd P Pfeifer ${ }^{1}$
}

\author{
1Department of Cancer Biology, Beckman Research Institute of the City of Hope, Duarte, California 91010, USA \\ 2Division of Information Sciences, Beckman Research Institute of the City of Hope, Duarte, California 91010, USA \\ 3Department of Clinical and Molecular Pharmacology, Beckman Research Institute of the City of Hope, Duarte, California 91010, USA
}

Corresponding author: Stella Tommasi, stommasi@coh.org

Received: 24 Oct 2008 Revisions requested: 5 Dec 2008 Revisions received: 18 Feb 2009 Accepted: 27 Feb 2009 Published: 27 Feb 2009

Breast Cancer Research 2009, 11:R14 (doi:10.1186/bcr2233)

This article is online at: http://breast-cancer-research.com/content/11/1/R14

(c) 2009 Tommasi et al.; licensee BioMed Central Ltd.

This is an open access article distributed under the terms of the Creative Commons Attribution License (http://creativecommons.org/licenses/by/2.0), which permits unrestricted use, distribution, and reproduction in any medium, provided the original work is properly cited.

\begin{abstract}
Introduction Aberrant methylation of $\mathrm{CpG}$ islands is a hallmark of cancer and occurs at an early stage in breast tumorigenesis. However, its impact on tumor development is not fully determined, and its potential as a diagnostic biomarker remains to be validated. Methylation profiling of invasive breast carcinoma has been largely explored. Conversely, very little and sparse information is available on early-stage breast cancer. To gain insight into the epigenetic switches that may promote and/ or contribute to the initial neoplastic events during breast carcinogenesis, we have analyzed the DNA methylation profile of ductal carcinoma in situ, a premalignant breast lesion with a great potential to progress toward invasive carcinoma.
\end{abstract}

Methods We have utilized a comprehensive and sensitive arraybased DNA mapping technique, the methylated-CpG island recovery assay, to profile the DNA methylation pattern in ductal carcinoma in situ. Differential methylation of $\mathrm{CpG}$ islands was compared genome-wide in tumor DNA versus normal DNA utilizing a statistical linear model in the LIMMA software package.
Results Using this approach, we have identified 108 significant $\mathrm{CpG}$ islands that undergo aberrant DNA methylation in ductal carcinoma in situ and stage I breast tumors, with methylation frequencies greater than or comparable with those of more advanced invasive carcinoma (50\% to $93 \%$ ). A substantial fraction of these hypermethylated $\mathrm{CpG}$ islands (32\% of the annotated $\mathrm{CpG}$ islands) is associated with several homeobox genes, such as the $T L X 1, H O X B 13$, and $H N F 1 B$ genes. Fiftythree percent of the genes hypermethylated in early-stage breast cancer overlap with known Polycomb targets and include homeobox genes and other developmental transcription factors.

Conclusions We have identified a series of new potential methylation biomarkers that may help elucidate the underlying mechanisms of breast tumorigenesis. More specifically, our results are suggestive of a critical role of homeobox gene methylation in the insurgence and/or progression of breast cancer.

\section{Introduction}

Breast cancer is a leading cause of cancer-related mortality in women, claiming over 400,000 lives per year worldwide. At the current breast cancer incidence rates, one in eight women is expected to develop the disease in her lifetime [1]. In spite of the high frequency, however, more than $90 \%$ of the breast cancer patients will survive if cancer is detected at an early stage and if treatment is begun promptly. Early detection is therefore extremely crucial for successful treatment and favorable prognosis, and emphasizes the need for new screening strategies for prompt intervention.
It is now widely recognized that aberrant epigenetic modifications play a crucial role in altering gene expression and inducing tumor formation [2]. Methylation of CpG-rich islands encompassing gene promoter regions is especially relevant for the silencing of important tumor suppressor genes and accounts for a growing number of diseases, including breast cancer [3-5]. Several genes involved in cell cycle regulation and apoptosis (CCND2, CDKN2A/p16, RASSF1A), DNA damage response (BRCA1), cell adhesion ( $\mathrm{CDH} 1)$ and cell signaling (ER, RAR $\beta 2$ ) have been reported to undergo promoter hypermethylation in breast carcinoma as well as in other 
tumor types [6-10]. High levels of some hypermethylated genes can be detected very early, in the ductal lavage and nipple aspirates of patients with ductal carcinoma in situ (DCIS) (a stage 0 breast cancer) and stage I tumors, with methylation frequencies comparable with those of more advanced, invasive breast cancers [11]. Epigenetic inactivation can also occur, at different levels depending on the gene examined, in benign diseases such as mammary epithelial hyperplasia and intraductal papillomas - but not in disease-free normal breast epithelium, proliferating lactating breast tissue or stromal cells [12]. In some cases, even the normal breast tissue adjacent to the tumor site can display high levels of promoter methylation, indicating that premalignant epigenetic changes have the potential to spread gradually from the tumor epicenter to the surrounding cells or that a field defect exists that promotes tumorigenesis $[13,14]$. These data altogether support the evidence that methylation-driven gene silencing is a frequent as well as a relatively early event in breast tumorigenesis and can be used as a tag to detect breast cancer lesions at their very first appearance.

Based on this assumption, several groups have attempted, in recent years, to establish multigene DNA methylation profiles for the detection and classification of breast cancer. Their studies were mostly restricted to methylation-specific PCR analysis or to the array-based screening of limited target panels, and thus failed to interrogate the entire 30,000 CpG island repertoire of the genome [12,15-20]. In addition, these studies as well as genome-wide DNA methylation mapping techniques were usually employed to scrutinize invasive and metastatic breast carcinomas (stage II tumors and higher) [2125]. These screening methods clearly overlook early epigenetic changes that may precede and/or promote invasive growth formation and offer limited diagnostic applications. Given the scattered and inadequate information available on early-stage breast tumors, it is not surprising that the search for breast cancer-specific methylation biomarkers has barely been translated into new reliable screening tests for the women at risk.

To fill the gaps in this area of research, we have analyzed the global methylation profile of $\mathrm{DCIS}$, a premalignant breast lesion with a high potential to progress toward invasive and metastatic carcinoma, through loss of the myoepithelial cell layer [26]. For DNA methylation analysis, we have utilized a high-throughput methodology, recently developed in our laboratory. The methylated-CpG island recovery assay (MIRA) is a very sensitive technique that exploits the strong affinity of the MBD2/MBD3L1 complex to double-stranded CpG-methylated DNA and allows one to detect cell-type-dependent differences in DNA methylation on a microarray platform $[27,28]$. We have applied this technology to identify a series of novel candidate tumor suppressor genes and potential DNA methylation biomarkers in DCIS. The present study provides an unprecedented snapshot of the global methylation profile in early-stage breast carcinoma (approximately 28,000 CpG islands were analyzed) and may lead to more accurate diagnostic tests for the prediction of breast cancer. Moreover, this work draws attention to the potential role of DNA methylation in the misregulation of homeobox genes during breast tumorigenesis. Homeobox-containing transcription factors control vital functional networks during tissue development and differentiation, and their aberrant expression has been often associated, in the mammary gland, with both morphological abnormalities and oncogenesis [29-31].

\section{Materials and methods Specimens}

Breast cancer samples of different histological type and grade were obtained from the City of Hope frozen tumor bank (City of Hope, Duarte, CA, USA). Tumors were staged according to the American Joint Committee on Cancer staging system protocol [32]. Tissue sections, derived from various DCIS specimens, were stained with $\mathrm{H} \& \mathrm{E}$ and were reviewed by a pathologist to confirm the presence and the extent of the lesions. Breast tissue obtained from non-neoplastic breast quadrants served as the normal control. All patients gave written informed consent and authorization for use of biological specimens. The present study was approved by the Institutional Review Board of the City of Hope Medical Center (IRB\# 97134).

\section{Methylated-CpG island recovery assay-assisted microarray analysis}

The MIRA and microarray analysis were performed as previously described with some modifications [27,28]. Genomic DNA was isolated from intraductal carcinomas (DCIS) and from matching normal tissues using either standard phenolchloroform extraction methods or the DNeasy purification kit (Qiagen, Valencia, CA, USA). Between 0.5 and $1 \mu \mathrm{g}$ DNA were double-digested with Msel (5'-TTAA) and Hhal (5'GCGC), to allow selective collection of substantially methylated CpG islands. Digested DNA was then incubated with a mixture of purified GST-tagged MBD2b and His-tagged MBD3L1 proteins (1:1) preincubated and bound to MagneGST glutathione particles (TM240; Promega, Madison, WI, USA). Binding reactions were carried out overnight at $4^{\circ} \mathrm{C}$ on a rocking platform, in $1 \times$ MIRA binding buffer $(10 \mathrm{mM}$ Tris$\mathrm{HCl}(\mathrm{pH} 7.5), 50 \mathrm{mM} \mathrm{NaCl}, 1 \mathrm{mM}$ ethylenediamine tetraacetic acid, $1 \mathrm{mM}$ dithiothreitol, $3 \mathrm{mM} \mathrm{MgCl}, 0.1 \%$ Triton-X100, $5 \%$ glycerol, $25 \mu \mathrm{g} / \mathrm{ml} \mathrm{BSA}$, and sonicated JM110 ( $\mathrm{dcm}$ minus) bacterial DNA). Pelleted glutathione beads were washed three times with a high salt-washing buffer (containing $700 \mathrm{mM}$ $\mathrm{NaCl}$ ), and the methylated DNA-enriched genomic DNA fraction was eluted with a guanidinium hydrochloride-containing buffer. DNA purification was carried out using the Qiaquick PCR purification kit according to the manufacturer's instructions (Qiagen). 
Following the MIRA pulldown, CpG-enriched DNA fragments were ligated to Msel linkers (upper strand sequence, 5'AGCAACTGTGCTATCCGAGGGAT; lower strand sequence, 5'-TAATCCCTCGGA) and were PCR-amplified for up to 20 cycles by real-time PCR. Two micrograms each of the amplicons from MIRA-enriched tumor DNA and from MIRAenriched normal control samples were labeled with Cy5-dCTP and Cy3-dCTP respectively (GE Healthcare Bio-Sciences Corp., Piscataway, NJ, USA), using a BioPrime Array CGH Genomic Labeling kit (Invitrogen, Carlsbad, CA, USA). The purified samples were then mixed, and hybridized to CpG island microarrays, according to the Agilent ChIP-on-chip protocol (version 9.0; Agilent Technologies, Santa Clara, CA, USA). Human CpG island microarrays contain 237,000 oligonucleotide probes covering 27,800 $\mathrm{CpG}$ islands and were purchased from Agilent Technologies (Santa Clara, CA, USA).

\section{Microarray data analysis}

Following hybridization and washing (Agilent ChIP-on-chip protocol, version 9.0), microarray slides were scanned using an Axon GenePix 4000b scanner (Molecular Devices, Sunnyvale, CA, USA) and images were quantified by GenePix Pro 6 software (Molecular Devices, Sunnyvale, CA, USA). Preprocessing of raw data and statistical analysis were performed as previously described with some modifications [33]. $\log _{2}{ }^{-}$ transformed ratios on each array were analyzed separately.

Probes were selected as positive if their ratios fell into more than the 98th percentile range on the array. Methylation regions (peaks) were defined as regions that contain a minimum of three positive probes. One negative probe was allowed within the peak as long as it was not present at the end of the region. The average of the $\log _{2}$ ratios of the positive probes within each peak was assigned as the peak score. Peaks were then annotated based on their location relative to known transcripts (UCSC hg18 refseq). Peaks overlapping with the $\pm 1,000$ bp region of a known transcription start site to $-10 \mathrm{~kb}$ of the transcription start site were annotated as upstream of the transcript, and peaks that overlap with the $\pm 1,000$ bp region of a known transcription termination site to $+10 \mathrm{~kb}$ downstream of the transcription termination site were annotated as downstream of the transcript. Peaks falling into known transcripts but not within 1,000 bp of either the transcription start site or the transcription termination site were denoted intragenic.

The transcripts that have either upstream, intragenic or downstream peaks in at least three out of six DCIS samples were selected as interesting targets, and are reported in Table 1. For peaks that fell into uncharacterized regions of the genome, the location of the $\mathrm{CpG}$ island was used instead (Table 2). Microarray data were deposited in the Gene Expression Omnibus repository [GEO:GSE14865].

\section{Combined bisulfite restriction analysis and bisulfite sequencing}

Total genomic DNA was isolated from human breast carcinoma and from normal tissues as described above. To analyze the methylation status of cytosines in several hypermethylated microarray targets, DNA $(1 \mu \mathrm{g})$ was treated with sodium bisulfite according to the manufacturer's protocol (EpiTect; Qiagen) and was subjected to combined bisulfite restriction analysis [34]. The PCR primer sequences used to amplify the candidate genes in bisulfite-treated DNA are available upon request. HeLa DNA was methylated in vitro with $\mathrm{M}$. Sssl methyltransferase and served as a positive control. For sequence analysis, the PCR products obtained after bisulfite conversion were cloned into the TOPO-TA cloning vector (Invitrogen) and up to 12 individual clones were sequenced.

\section{Results \\ Genome-wide detection of methylated CpG islands in DCIS}

The MIRA, used in combination with microarray analysis, is a high-resolution mapping technique and has proven successful in profiling global DNA methylation patterns in lung cancer $[33,35]$. In the present study we have applied this sensitive method to establish the methylation status of $\mathrm{CpG}$ islands in early-stage ductal carcinoma and to investigate its potential role in the initiation and development of breast cancer. Six DCIS were screened for methylation by MIRA-based microarrays. To ensure consistency with the initial clinical diagnosis, and the presence of epithelial cells in the sample, histological examination of the specimens (both cancer samples and their matching normal) was conducted with the help of a pathologist.

The H\&E slides derived from tumor samples displayed a predominant DCIS component (70\% to $80 \%$ ) over normal stromal tissue and infiltrating lymphocytes (as shown for DCIS number 4 in Figure 1, upper right panel). Since contamination with low amounts of normal cells is not expected to interfere with the overall interpretation of the methylation data, tumor specimens were not subjected to further microdissection. Normal healthy breast tissues adjacent to the lesions and obtained at the time of the surgical resection were used as a control. When matching normal tissue was not available, a DNA mixture from several normal breast tissues was used as a control. To avoid epigenetic variations due to age, reproductive state and/or cancer stage, we pooled together, whenever possible, DNA of normal breast tissues derived from comparable donors (same age frame, tumor stage, estrogen receptor/progesterone receptor status, and so forth).

Genomic DNA isolated from DCIS and normal tissue was subjected to MIRA enrichment, labeling, and subsequent microarray analysis, as depicted in detail in Figure 1. DCIS-specific methylation regions (peaks) were defined using stringent statistical criteria, and a full description of the algorithm used for 
Breast Cancer Research Vol 11 No 1 Tommasi et al.

Table 1

Methylated target genes identified by methylated-CpG island recovery assay-assisted microarray analysis

\begin{tabular}{|c|c|c|c|c|c|c|c|}
\hline Target number & Gene & Description & Gene location & Strand & $\begin{array}{l}\text { Position relative to } \\
\text { gene }^{a}\end{array}$ & Average ratio ${ }^{b}$ & Count \\
\hline $1^{*}$ & FOXE1 & Forkhead box E1 & $\begin{array}{l}\text { Chr9: } 99655357 \text { to } \\
99658818\end{array}$ & + & Downstream & 13.76 & 4 \\
\hline 2 & SEMA6C & Semaphorin $6 \mathrm{C}$ & $\begin{array}{l}\text { Chr1: } 149370786 \text { to } \\
149385728\end{array}$ & - & Downstream & 6.40 & 4 \\
\hline $3^{*}$ & $\mathrm{HNF} 1 \mathrm{~B}^{\mathrm{c}}$ & Hnf1 homeobox B & $\begin{array}{l}\text { Chr17: } 33120546 \text { to } \\
\text { 33179209 }\end{array}$ & - & Upstream & 6.06 & 4 \\
\hline 4 & OTX1 & Orthodenticle homeobox 1 & $\begin{array}{l}\text { Chr2: } 63131468 \text { to } \\
63137816\end{array}$ & + & Intragenic & 4.83 & 4 \\
\hline $5^{\star}$ & TLX1 & T-cell leukemia homeobox 1 & $\begin{array}{l}\text { Chr10: } 102881050 \\
\text { to } 102887535\end{array}$ & + & Intragenic & 4.50 & 4 \\
\hline 6 & ESAM & $\begin{array}{l}\text { Endothelial cell adhesion } \\
\text { molecule }\end{array}$ & $\begin{array}{l}\text { Chr11: } 124128228 \\
\text { to } 124137433\end{array}$ & - & Intragenic & 4.16 & 4 \\
\hline $7^{*}$ & CNTNAP1 & Contactin associated protein 1 & $\begin{array}{l}\text { Chr1 17: } 38088158 \text { to } \\
38105358\end{array}$ & + & Intragenic & 3.94 & 4 \\
\hline $8^{*}$ & GFI1 & $\begin{array}{l}\text { Growth factor independent } 1 \\
\text { transcription repressor }\end{array}$ & $\begin{array}{l}\text { Chr1: } 92712905 \text { to } \\
92725021\end{array}$ & - & Intragenic & 3.64 & 4 \\
\hline $9^{*}$ & RASL10A & Ras-like, family 10 , member $A$ & $\begin{array}{l}\text { Chr22: } 28038921 \text { to } \\
\text { 28041748 }\end{array}$ & - & Intragenic & 3.42 & 4 \\
\hline $10^{*}$ & IFNA8 & Interferon, alpha 8 & $\begin{array}{l}\text { Chr9: } 21399146 \text { to } \\
21400184\end{array}$ & + & Upstream & 3.41 & 4 \\
\hline 11 & ERGIC2 & Ergic and golgi 2 & $\begin{array}{l}\text { Chr12: } 29384845 \text { to } \\
29425410\end{array}$ & - & Upstream & 3.39 & 4 \\
\hline 12 & $\mathrm{PCDH7}$ & Protocadherin 7 & $\begin{array}{l}\text { Chr4: } 30331134 \text { to } \\
30757519\end{array}$ & + & Intragenic & 3.16 & 4 \\
\hline 13 & RASGRP2 & Ras guanyl releasing protein 2 & $\begin{array}{l}\text { Chr11: } 64250958 \text { to } \\
64269504\end{array}$ & - & Intragenic & 3.01 & 4 \\
\hline 14 & NFATC1 & $\begin{array}{l}\text { Nuclear factor of activated T- } \\
\text { cells } 1\end{array}$ & $\begin{array}{l}\text { Chr18: } 75256759 \text { to } \\
75390311\end{array}$ & + & Intragenic & 2.93 & 4 \\
\hline 15 & RLTPR & $\begin{array}{l}\text { Rgd motif, leucine-rich repeats, } \\
\text { tropomodulin domain and } \\
\text { proline-rich containing gene }\end{array}$ & $\begin{array}{l}\text { Chr16: } 66236530 \text { to } \\
66248973\end{array}$ & + & Intragenic & 2.75 & 4 \\
\hline 16 & AK123344 & Hypothetical gene & $\begin{array}{l}\text { Chr10: } 102979341 \\
\text { to } 102985256\end{array}$ & + & Downstream & 16.49 & 3 \\
\hline 17 & C1orf114 & $\begin{array}{l}\text { Chromosome } 1 \text { open reading } \\
\text { frame } 114\end{array}$ & $\begin{array}{l}\text { Chr1: } 167630737 \text { to } \\
167663294\end{array}$ & - & Upstream & 11.13 & 3 \\
\hline 18 & TRPS1 & $\begin{array}{l}\text { Trichorhinophalangeal } \\
\text { syndrome I }\end{array}$ & $\begin{array}{l}\text { Chr8: } 116489899 \text { to } \\
116750402\end{array}$ & - & Intragenic & 11.07 & 3 \\
\hline 19 & PCDHGA12 & $\begin{array}{l}\text { Protocadherin gamma } \\
\text { subfamily } A, 12\end{array}$ & $\begin{array}{l}\text { Chr5: } 140790341 \text { to } \\
140872730\end{array}$ & + & Upstream & 11.02 & 3 \\
\hline 20 & C14orf25 & $\begin{array}{l}\text { Chromosome } 14 \text { open reading } \\
\text { frame } 25\end{array}$ & $\begin{array}{l}\text { Chr14: } 37150207 \text { to } \\
37580397\end{array}$ & + & Upstream & 10.34 & 3 \\
\hline 21 & CDKN2A & $\begin{array}{l}\text { Cyclin-dependent kinase } \\
\text { inhibitor } 2 A(P 16)\end{array}$ & $\begin{array}{l}\text { Chr9: } 21957750 \text { to } \\
21984490\end{array}$ & - & Downstream & 9.86 & 3 \\
\hline 22 & SCRT2 & $\begin{array}{l}\text { Scratch homolog 2, zinc finger } \\
\text { protein }\end{array}$ & $\begin{array}{l}\text { Chr20: } 590240 \text { to } \\
604823\end{array}$ & - & Downstream & 9.47 & 3 \\
\hline 23 & BCOR & Bcl6 co-repressor & $\begin{array}{l}\text { Chrx: } 39795443 \text { to } \\
39921526\end{array}$ & - & Upstream & 9.43 & 3 \\
\hline 24 & KHDC1 & $\begin{array}{l}\text { Kh homology domain } \\
\text { containing } 1\end{array}$ & $\begin{array}{l}\text { Chr6: } 74007759 \text { to } \\
74076659\end{array}$ & - & Upstream & 9.00 & 3 \\
\hline $25^{\star}$ & $\mathrm{NXPH} 1$ & Neurexophilin 1 & $\begin{array}{l}\text { Chr7: } 8440109 \text { to } \\
8759118\end{array}$ & + & Intragenic & 8.83 & 3 \\
\hline
\end{tabular}




\begin{tabular}{|c|c|c|c|c|c|c|c|}
\hline 26 & CNR1 & Cannabinoid receptor 1 (brain) & $\begin{array}{l}\text { Chr6: } 88910156 \text { to } \\
88932281\end{array}$ & - & Upstream & 8.78 & 3 \\
\hline 27 & $\mathrm{BC} 039088$ & Hypothetical gene & $\begin{array}{l}\text { Chr5: } 43050280 \text { to } \\
43054670\end{array}$ & - & Upstream & 8.61 & 3 \\
\hline 28 & EVX2 & Even-skipped homeobox 2 & $\begin{array}{l}\text { Chr2: } 176653080 \text { to } \\
176656936\end{array}$ & - & Downstream & 8.43 & 3 \\
\hline $29^{*}$ & MT1E & Metallothionein 1E & $\begin{array}{l}\text { Chr16: } 55217085 \text { to } \\
55218525\end{array}$ & + & Upstream & 8.36 & 3 \\
\hline $30^{*}$ & $\mathrm{NR} 2 \mathrm{~F} 2$ & $\begin{array}{l}\text { Nuclear receptor subfamily } 2 \text {, } \\
\text { group F, member } 2\end{array}$ & $\begin{array}{l}\text { Chr15: } 94674950 \text { to } \\
94683047\end{array}$ & + & Downstream & 8.24 & 3 \\
\hline 31 & $\mathrm{HOXC13}$ & Homeobox $\mathrm{C} 13$ & $\begin{array}{l}\text { Chr12: } 52618843 \text { to } \\
52626595\end{array}$ & + & Upstream & 8.08 & 3 \\
\hline 32 & HOXD8 & Homeobox D8 & $\begin{array}{l}\text { Chr2: } 176702722 \text { to } \\
176704974\end{array}$ & + & Upstream & 7.97 & 3 \\
\hline 33 & SYCP2L & $\begin{array}{l}\text { Synaptonemal complex protein } \\
2 \text {-like }\end{array}$ & $\begin{array}{l}\text { Chr6: } 10995049 \text { to } \\
11082527\end{array}$ & + & Upstream & 7.58 & 3 \\
\hline 34 & PCDHGB6 & $\begin{array}{l}\text { Protocadherin gamma } \\
\text { subfamily } B, 6\end{array}$ & $\begin{array}{l}\text { Chr5: } 140767953 \text { to } \\
140872730\end{array}$ & + & Intragenic & 7.37 & 3 \\
\hline 35 & ACTA1 & Actin, alpha 1, skeletal muscle & $\begin{array}{l}\text { Chr1: } 227633615 \text { to } \\
227636466\end{array}$ & - & Upstream & 7.36 & 3 \\
\hline $36^{*}$ & PRDM14 & Pr domain containing 14 & $\begin{array}{l}\text { Chr8: } 71126576 \text { to } \\
71146116\end{array}$ & - & Intragenic & 7.27 & 3 \\
\hline $37^{*}$ & HOXB13 & Homeobox B13 & $\begin{array}{l}\text { Chr17: } 44157124 \text { to } \\
44161110\end{array}$ & - & Intragenic & 6.91 & 3 \\
\hline 38 & OTX2 & Orthodenticle homeobox 2 & $\begin{array}{l}\text { Chr14: } 56337177 \text { to } \\
56346937\end{array}$ & - & Upstream & 6.70 & 3 \\
\hline 39 & ZNF711 & Zinc finger protein 711 & $\begin{array}{l}\text { Chrx: } 84385652 \text { to } \\
84415025\end{array}$ & + & Upstream & 6.63 & 3 \\
\hline $40^{*}$ & NR2E1 & $\begin{array}{l}\text { Nuclear receptor subfamily } 2 \text {, } \\
\text { group } E \text {, member } 1\end{array}$ & $\begin{array}{l}\text { Chr6: } 108593954 \text { to } \\
108616706\end{array}$ & + & Intragenic & 6.44 & 3 \\
\hline $41^{*}$ & TAC1 & Tachykinin, precursor 1 & $\begin{array}{l}\text { Chr7: } 97199206 \text { to } \\
97207720\end{array}$ & + & Upstream & 6.37 & 3 \\
\hline $42^{*}$ & CPEB1 & $\begin{array}{l}\text { Cytoplasmic polyadenylation } \\
\text { element binding protein } 1\end{array}$ & $\begin{array}{l}\text { Chr15: } 81009005 \text { to } \\
81113783\end{array}$ & - & Upstream & 5.99 & 3 \\
\hline 43 & NKAPL & Nfkb activating protein-like & $\begin{array}{l}\text { Chr6: } 28335076 \text { to } \\
28336715\end{array}$ & + & Upstream & 5.86 & 3 \\
\hline 44 & NKX6-2 & Nk6 homeobox 2 & $\begin{array}{l}\text { Chr10: } 134448309 \\
\text { to } 134449527\end{array}$ & - & Downstream & 5.72 & 3 \\
\hline $45^{\star}$ & TGIF2 & $\begin{array}{l}\text { Tgfb-induced factor homeobox } \\
2\end{array}$ & $\begin{array}{l}\text { Chr20: } 34635423 \text { to } \\
34655766\end{array}$ & + & Upstream & 5.60 & 3 \\
\hline 46 & CR596471 & Hypothetical gene & $\begin{array}{l}\text { Chrx: } 133511720 \text { to } \\
133522094\end{array}$ & + & Upstream & 5.56 & 3 \\
\hline 47 & EVX2 & Even-skipped homeobox 2 & $\begin{array}{l}\text { Chr2: } 176653080 \text { to } \\
176656936\end{array}$ & - & Intragenic & 5.55 & 3 \\
\hline 48 & AX747981 & Hypothetical gene & $\begin{array}{l}\text { Chr8: } 96148213 \text { to } \\
96154324\end{array}$ & - & Upstream & 5.48 & 3 \\
\hline 49 & ST8SIA3 & $\begin{array}{l}\text { St8 alpha- } N \text {-acetyl-neuraminide } \\
\text { alpha-2,8-sialyltransferase } 3\end{array}$ & $\begin{array}{l}\text { Chr18: } 53170718 \text { to } \\
\text { 53187159 }\end{array}$ & + & Intragenic & 5.47 & 3 \\
\hline 50 & WT1 & Wilms tumor 1 & $\begin{array}{l}\text { Chr11: } 32365900 \text { to } \\
32413663\end{array}$ & - & Intragenic & 5.40 & 3 \\
\hline 51 & BARHL2 & Barh-like homeobox 2 & $\begin{array}{l}\text { Chr1: } 90950167 \text { to } \\
90955382\end{array}$ & - & Upstream & 5.39 & 3 \\
\hline
\end{tabular}


Table 1 (Continued)

Methylated target genes identified by methylated-CpG island recovery assay-assisted microarray analysis

\begin{tabular}{|c|c|c|c|c|c|c|c|}
\hline 52 & IRX1 & Iroquois homeobox 1 & $\begin{array}{l}\text { Chr5: } 3649167 \text { to } \\
3654517\end{array}$ & + & Intragenic & 5.39 & 3 \\
\hline 53 & KLF11 & Kruppel-like factor 11 & $\begin{array}{l}\text { Chr2: } 10101132 \text { to } \\
10112414\end{array}$ & + & Upstream & 5.26 & 3 \\
\hline 54 & HLXB9 & Homeobox Hb9 & $\begin{array}{l}\text { Chr7: } 156479507 \text { to } \\
156496108\end{array}$ & - & Upstream & 5.25 & 3 \\
\hline 55 & NKX2-8 & Nk2 homeobox 8 & $\begin{array}{l}\text { Chr14: } 36118966 \text { to } \\
36121537\end{array}$ & - & Upstream & 5.20 & 3 \\
\hline 56 & ZFP91 & $\begin{array}{l}\text { Zinc finger protein } 91 \text { homolog } \\
\text { (mouse) }\end{array}$ & $\begin{array}{l}\text { Chr11: } 58103162 \text { to } \\
58145091\end{array}$ & + & Upstream & 5.07 & 3 \\
\hline 57 & LHX2 & Lim homeobox 2 & $\begin{array}{l}\text { Chr9: } 125813709 \text { to } \\
125835263\end{array}$ & + & Intragenic & 5.04 & 3 \\
\hline 58 & MEIS1 & Meis homeobox 1 & $\begin{array}{l}\text { Chr2: } 66516036 \text { to } \\
66653085\end{array}$ & + & Downstream & 5.00 & 3 \\
\hline $59^{*}$ & PAX2 & Paired box 2 & $\begin{array}{l}\text { Chr10: } 102495457 \\
\text { to } 102579688\end{array}$ & + & Intragenic & 4.95 & 3 \\
\hline $60^{*}$ & LHX9 & Lim homeobox 9 & $\begin{array}{l}\text { Chr1: } 196153139 \text { to } \\
196165896\end{array}$ & + & Intragenic & 4.81 & 3 \\
\hline 61 & GRASP & $\begin{array}{l}\text { Grp1-associated scaffold } \\
\text { protein }\end{array}$ & $\begin{array}{l}\text { Chr12: } 50687014 \text { to } \\
\text { 50695938 }\end{array}$ & + & Upstream & 4.78 & 3 \\
\hline 62 & LHX8 & Lim homeobox 8 & $\begin{array}{l}\text { Chr1: } 75366706 \text { to } \\
75399806\end{array}$ & + & Intragenic & 4.77 & 3 \\
\hline 63 & HOXD12 & Homeobox D12 & $\begin{array}{l}\text { Chr2: } 176672775 \text { to } \\
176673734\end{array}$ & + & Upstream & 4.66 & 3 \\
\hline 64 & PAX5 & Paired box 5 & $\begin{array}{l}\text { Chr9: } 36828530 \text { to } \\
37024476\end{array}$ & - & Intragenic & 4.56 & 3 \\
\hline 65 & LBX1 & Ladybird homeobox 1 & $\begin{array}{l}\text { Chr10: } 102976722 \\
\text { to } 102978707\end{array}$ & - & Downstream & 4.53 & 3 \\
\hline 66 & EGFR & $\begin{array}{l}\text { Epidermal growth factor } \\
\text { receptor }\end{array}$ & $\begin{array}{l}\text { Chr7: } 55054218 \text { to } \\
55242525\end{array}$ & + & Upstream & 4.45 & 3 \\
\hline 67 & ODZ3 & Odz, odd Oz/ten-m homolog 3 & $\begin{array}{l}\text { Chr4: } 183302134 \text { to } \\
183508463\end{array}$ & + & Upstream & 4.40 & 3 \\
\hline 68 & TM7SF4 & $\begin{array}{l}\text { Transmembrane } 7 \text { superfamily } \\
\text { member } 4\end{array}$ & $\begin{array}{l}\text { Chr8: } 105421230 \text { to } \\
105438092\end{array}$ & + & Upstream & 4.22 & 3 \\
\hline 69 & ZNF311 & Zinc finger protein 311 & $\begin{array}{l}\text { Chr6: } 29070573 \text { to } \\
29081014\end{array}$ & - & Downstream & 4.09 & 3 \\
\hline 70 & $\mathrm{PCDH} 19$ & Protocadherin 19 & $\begin{array}{l}\text { Chrx: } 99433297 \text { to } \\
99551927\end{array}$ & - & Intragenic & 4.06 & 3 \\
\hline 71 & FLJ45983 & Hypothetical gene & $\begin{array}{l}\text { Chr10: } 8132418 \text { to } \\
8135453\end{array}$ & - & Upstream & 3.84 & 3 \\
\hline 72 & AX747375 & Hypothetical gene & $\begin{array}{l}\text { Chr19: } 41955897 \text { to } \\
41958529\end{array}$ & + & Downstream & 3.83 & 3 \\
\hline 73 & PPP2R2C & $\begin{array}{l}\text { Protein phosphatase } 2 \\
\text { regulatory subunit } B, \text { gamma } \\
\text { isoform }\end{array}$ & $\begin{array}{l}\text { Chr4: } 6373205 \text { to } \\
6525227\end{array}$ & - & Intragenic & 3.58 & 3 \\
\hline 74 & EMX1 & Empty spiracles homeobox 1 & $\begin{array}{l}\text { Chr2: } 72998111 \text { to } \\
73015528\end{array}$ & + & Intragenic & 3.57 & 3 \\
\hline 75 & PRKCSH & $\begin{array}{l}\text { Protein kinase } \mathrm{C} \text { substrate } \\
80 \mathrm{~K}-\mathrm{H}\end{array}$ & $\begin{array}{l}\text { Chr19: } 11407268 \text { to } \\
11422782\end{array}$ & + & Upstream & 3.56 & 3 \\
\hline 76 & FZD1 & Frizzled homolog 1 & $\begin{array}{l}\text { Chr7: } 90731718 \text { to } \\
90736068\end{array}$ & + & Intragenic & 3.52 & 3 \\
\hline 77 & LBX2 & Ladybird homeobox 2 & $\begin{array}{l}\text { Chr2: } 74578151 \text { to } \\
74583951\end{array}$ & - & Upstream & 3.42 & 3 \\
\hline
\end{tabular}




\begin{tabular}{|c|c|c|c|c|c|c|c|}
\hline 78 & Hoxc13 & Homeobox $\mathrm{C} 13$ & $\begin{array}{l}\text { Chr12: } 52618842 \text { to } \\
52626595\end{array}$ & + & Intragenic & 3.40 & 3 \\
\hline 79 & MT1A & Metallothionein $1 \mathrm{~A}$ & $\begin{array}{l}\text { Chr16: } 55230078 \text { to } \\
55231500\end{array}$ & + & Upstream & 3.36 & 3 \\
\hline 80 & DLX5 & Distal-less homeobox 5 & $\begin{array}{l}\text { Chr7: } 96487637 \text { to } \\
96492079\end{array}$ & - & Intragenic & 3.06 & 3 \\
\hline 81 & LDOC1L & $\begin{array}{l}\text { Leucine zipper, downregulated } \\
\text { in cancer } 1 \text {-like }\end{array}$ & $\begin{array}{l}\text { Chr22: } 43267113 \text { to } \\
43272669\end{array}$ & - & Intragenic & 2.30 & 3 \\
\hline
\end{tabular}

aFor definitions of upstream, intragenic, and downstream, see Materials and methods (Microarray data analysis). The transcripts that have either upstream, intragenic or downstream peaks in at least three out of six DCIS samples were selected as positive targets. *Gene targets verified by combined bisulfite restriction analysis assays or bisulfite sequencing. ${ }^{b}$ Average of the $\log _{2}$ ratios assigned to positive peaks across the six DCIS. cHomeobox genes are indicated in bold.

the analysis is provided in Materials and methods. Using this approach, we generated a list of over 100 significant CpG islands that display aberrant methylation in early-stage breast cancer and were methylation-positive in at least three out of six DCIS examined (Tables 1 and 2). Consistent with a potential role in transcriptional silencing, anomalous levels of DNA methylation were detected at the $5^{\prime}$ end of known genes, in proximity of promoter regions or further upstream. Numerous $\mathrm{CpG}$ islands mapping to intragenic or downstream regions of annotated genes, however, were also found to be heavily methylated in DCIS (Table 1).

\section{Verification of tumor-specific DNA methylation by combined bisulfite restriction analysis}

We next confirmed tumor-specific methylation for several of the targets identified through array analysis using the BstUI combined bisulfite restriction analysis (COBRA) assay. In this assay, bisulfite-converted DNA is PCR-amplified using genespecific primers and is then digested with the restriction endonuclease BstUI, which recognizes the sequence 5'-CGCG. Unmethylated restriction sites are converted to 5'-TGTG by sodium bisulfite and PCR and resist BstUI digestion, whereas methylated sites remain unchanged and are cleaved by the enzyme. The digested fragments displayed on agarose gels are thus indicative of methylated BstUl sites in the region analyzed.

Representative examples of COBRA results are shown in Figure 2. Here, we have inspected the methylation status of the candidate genes ranked numbers $5,7,8,29,40,42$ and 54 on the list of differentially methylated targets (corresponding to T-cell leukemia homeobox 1 (TLX1), CNTNAP1, GFI1, MT1E, NR2E1, CPEB1 and homeobox HB9 (HLXB9), respectively). All seven $\mathrm{CpG}$ islands appear methylated with high specificity (no or very little methylation detected in normal breast tissue) in the DCIS analyzed, and with methylation frequencies ranging from $50 \%$ to $83 \%$ depending on the target gene. No target region scrutinized so far exhibited robust CpG methylation across all six intraductal carcinomas (Table 1 and data not shown). Interestingly, we noticed that one-third of the CpG islands identified by microarray analysis (26 out of the 81 annotated hits) are associated with members of various homeobox superfamilies (HOX, LHX,NKX, PAX, and so forth) and are preferential targets of de novo methylation in early-stage breast cancer. These master regulators control vital functional networks during tissue development and differentiation, and are misregulated in a variety of malignancies, including breast cancer $[29,36]$.

To explore this interesting finding in more detail, we then focused our attention on several homeobox genes. Besides the CpG islands associated with the TLX1 gene and with the $H L X B 9$ gene (Figure 2), we have examined the methylation status of the $H N F 1 B$ and $H O X B 13$ candidate gene targets (hit numbers 3 and 37, respectively). An uncharacterized $\mathrm{CpG}$ island located on chromosome 7 (CGI 7:48 and hit number 5 in Table 2) was also selected for COBRA analysis. Although some levels of methylation could be detected in normal tissues, methylation of $H O X B 13, H N F 1 B$, and CGI 7:48 CpG islands was clearly more pronounced in intraductal carcinomas (Figure 3, upper panel and Figure 4). Considering that the same matching controls were negative in other COBRA assays (Figure 2), we can exclude that the methylation signal observed here in normal samples is due to contamination with neighboring cancer cells. Rather, distinct cell populations within the normal breast tissue may display specific DNA methylation profiles, as recently established [37]. Differential promoter hypermethylation in benign breast epithelium derived from cancer patients can also be a function of age in a genespecific manner [16,38]. Likewise, the occurrence of unmethylated alleles in the cancer samples may reflect the heterogeneity of $\mathrm{CpG}$ methylation within the cell populations of the tumor itself, but also the presence of normal cells in the specimens.

\section{Confirmation of the methylation pattern in invasive breast tumors}

To corroborate the DCIS-specific methylation profiles of $T L X 1$, CGI 7:48, $H O X B 13$, and $H N F 1 B$, we then extended the COBRA analysis to a series of primary breast tumors of differ- 
Breast Cancer Research Vol 11 No 1 Tommasi et al.

Table 2

\begin{tabular}{|c|c|c|c|c|}
\hline Target number & Symbol & CpG island location ${ }^{\mathrm{a}}$ & Average ratiob & Count \\
\hline 1 & CGI 1:42 & Chr1: 38714506 to 38714991 & 6.27 & 4 \\
\hline 2 & CGI 6:60 & Chr6: 106535804 to 106536465 & 4.69 & 4 \\
\hline 3 & CGI 2:112 & Chr2: 239419845 to 239420943 & 4.22 & 4 \\
\hline 4 & CGI 4:34 & Chr4: 174658599 to 174659018 & 2.94 & 4 \\
\hline $5^{\star}$ & CGI 7:48 & Chr7: 35460738 to 35461227 & 17.26 & 3 \\
\hline 6 & CGI 8:121 & Chr8: 100054909 to 100056159 & 16.81 & 3 \\
\hline 7 & CGI 10:46b & Chr10: 119484483 to 119484981 & 15.44 & 3 \\
\hline 8 & CGI 17:16 & Chr17: 44182434 to 44182640 & 13.96 & 3 \\
\hline 9 & CGI 7:351 & Chr7: 129205522 to 129209745 & 11.56 & 3 \\
\hline 10 & CGI 6:19 & Chr6: 27755772 to 27755984 & 10.16 & 3 \\
\hline 11 & CGI 8:31 & Chr8: 81968510 to 81968882 & 8.45 & 3 \\
\hline 12 & CGI 22:48 & Chr22: 44655029 to 44655728 & 7.98 & 3 \\
\hline 13 & CGI 2:77 & Chr2: 176639821 to 176640909 & 7.91 & 3 \\
\hline 14 & CGI 5:47 & Chr5: 176039674 to 176040127 & 7.78 & 3 \\
\hline 15 & CGI 7:29 & Chr7: 129210233 to 129210591 & 7.60 & 3 \\
\hline 16 & CGI 3:47 & Chr3: 134875805 to 134876344 & 6.58 & 3 \\
\hline $17^{\star}$ & CGI 4:35 & Chr4: 24699204 to 24699608 & 6.22 & 3 \\
\hline 18 & CGI 6:18 & Chr6: 27571155 to 27571358 & 6.18 & 3 \\
\hline 19 & CGI 7:277 & Chr7: 154857318 to 154860615 & 5.91 & 3 \\
\hline 20 & CGI 10:46 & Chr10: 102409137 to 102409658 & 5.84 & 3 \\
\hline 21 & CGI 4:21 & Chr4: 174657922 to 174658134 & 5.53 & 3 \\
\hline 22 & CGI X:92 & Chrx: 136459742 to 136460985 & 4.81 & 3 \\
\hline 23 & CGI 22:18 & Chr22: 47762399 to 47762664 & 4.15 & 3 \\
\hline 24 & CGI 1:130 & Chr1: 199774402 to 199775940 & 3.77 & 3 \\
\hline 25 & CGI 5:26 & Chr5: 3379328 to 3379645 & 3.42 & 3 \\
\hline 26 & CGI 5:87 & Chr5: 134853297 to 134854395 & 3.16 & 3 \\
\hline 27 & CGI 8:72 & Chr8: 1100465 to 1101480 & 2.35 & 3 \\
\hline
\end{tabular}

aFor uncharacterized gene targets, $\mathrm{CpG}$ island location was assigned instead of gene location. ${ }^{\mathrm{b}}$ Average of the log ${ }_{2}$ ratios assigned to positive peaks across the six DCIS. Targets with methylated peaks within the CpG island in at least three out of six DCIS samples were considered significant. *Unknown CpG islands verified by combined bisulfite restriction analysis assays or bisulfite sequencing.

ent histological type and stage (Figures 3 and 5, lower panels and Figure 4). The TLX1 CpG island was methylated in 13 out of the 16 stage I breast tumors $(81 \%)$ and in six out of the eight stage II invasive carcinomas (75\%). Likewise, the CpG island located on chromosome 7 (CGI 7:48) was methylated in almost every stage I tumor examined (93\%) and in 15 out of the 17 more advanced tumors (stages II and III tumors, 88\%). Of the 32 invasive breast carcinomas tested (15 cases of stage I tumors, nine cases of stage II tumors and eight cases of stage III tumors) 29 displayed higher levels of methylation relative to their matching controls within the $H O X B 13$ element (91\%), whereas the HNF1B CpG island was methylated in 21 tumor samples (66\%) (partial COBRA data are shown in Figure 4). Stage I tumors already exhibited a significant degree of methylation ( $87 \%$ for $H O X B 13$ and $73 \%$ for $H N F 1 B$ ), confirming the rapid and early nature of epigenetic reprogramming in breast cancer (Figure 4, representative COBRA analysis and Table 3).

Rodriguez and colleagues have reported recently that hypermethylation of the HOXB13 gene is a late event in breast tumorigenesis [39]. This apparent discrepancy with our results can be ascribed to the different methods used for the analysis (methylation-specific PCR versus our genome-wide DNA 


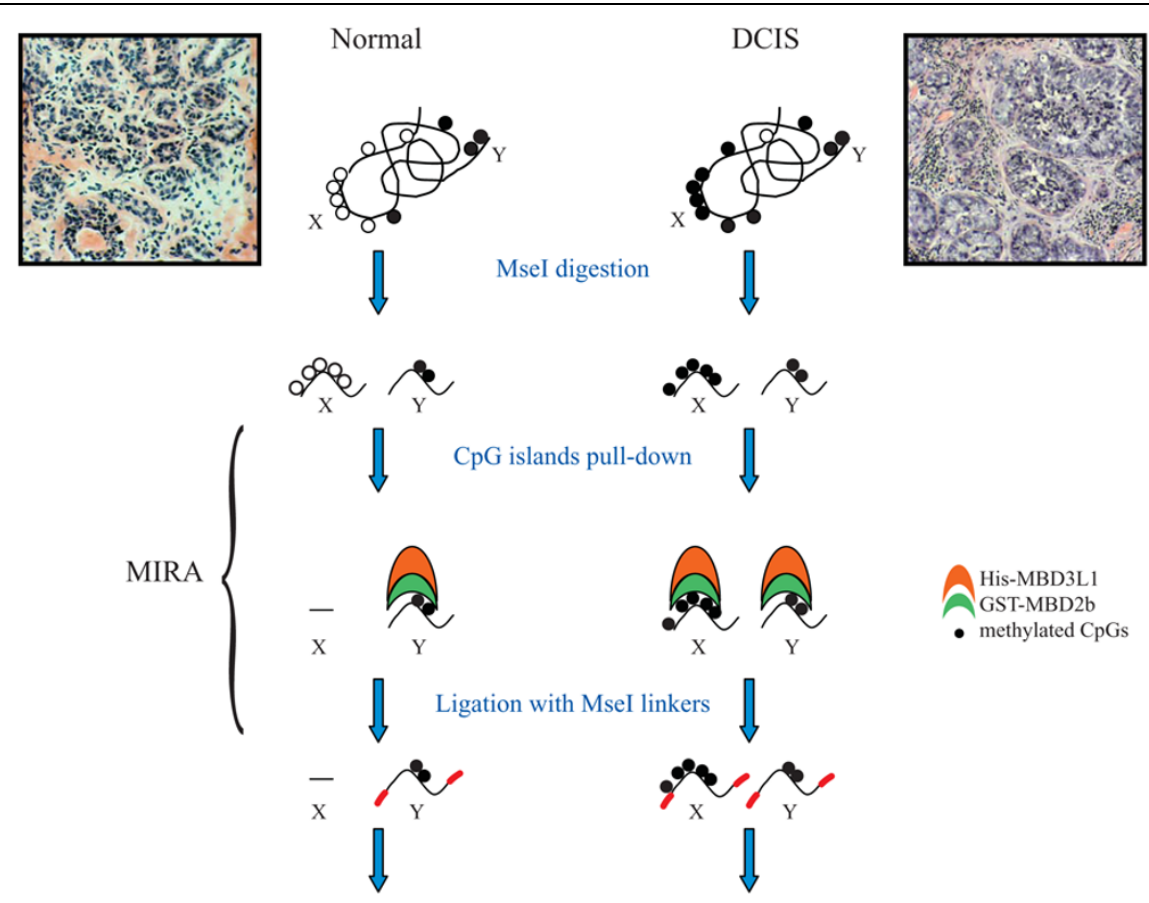

PCR amplification of MIRA-enriched fractions

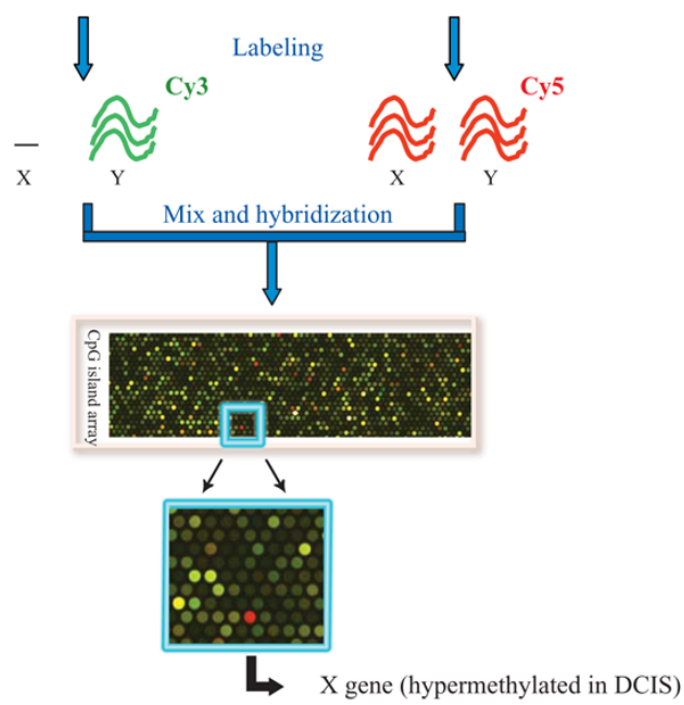

Outline of the methylated-CpG island recovery assay-assisted $\mathrm{CpG}$ island microarray analysis. Prior to microarray analysis, tissue sections, derived from six independent ductal carcinomas in situ (DCIS) and their matching normal areas, were stained with H\&E and validated by a pathologist. Genomic DNA derived from tumor specimens and matching normal tissue was then subjected to methylated-CpG island recovery assay (MIRA) pulldown as described in Materials and methods. MIRA-enriched fractions were labeled with different dyes, mixed, and hybridized to CpG island-Agilent slides and the relative enrichment factors between different tissues were determined by statistical analysis.

methylation profiling), the different specimens examined in the two studies (invasive-stage breast carcinomas versus DCIS), and the different location of the $\mathrm{CpG}$ islands on the HOXB13 gene (promoter versus an intragenic $\mathrm{CpG}$ island, target number 37). Methylation of this intragenic $\mathrm{CpG}$ island is an early event in breast cancer development and may precede promoter methylation. Whether this intragenic $\mathrm{CpG}$ island affects the $H O X B 13$ gene expression remains to be seen.
Two additional targets, the growth factor transcriptional repressor GFI1 gene (target number 8 ) and the nuclear receptor NR2E1 gene (target number 40), were inspected to evaluate the level of methylation in early-stage breast carcinomas. In agreement with the MIRA results, we found that the GFI1 CpG island was hypermethylated in 14 out of the 18 tumors examined (six DCIS and 12 stage I tumors, 78\%) while the NR2E1 target region was methylated in 11 out of the 21 early-stage 


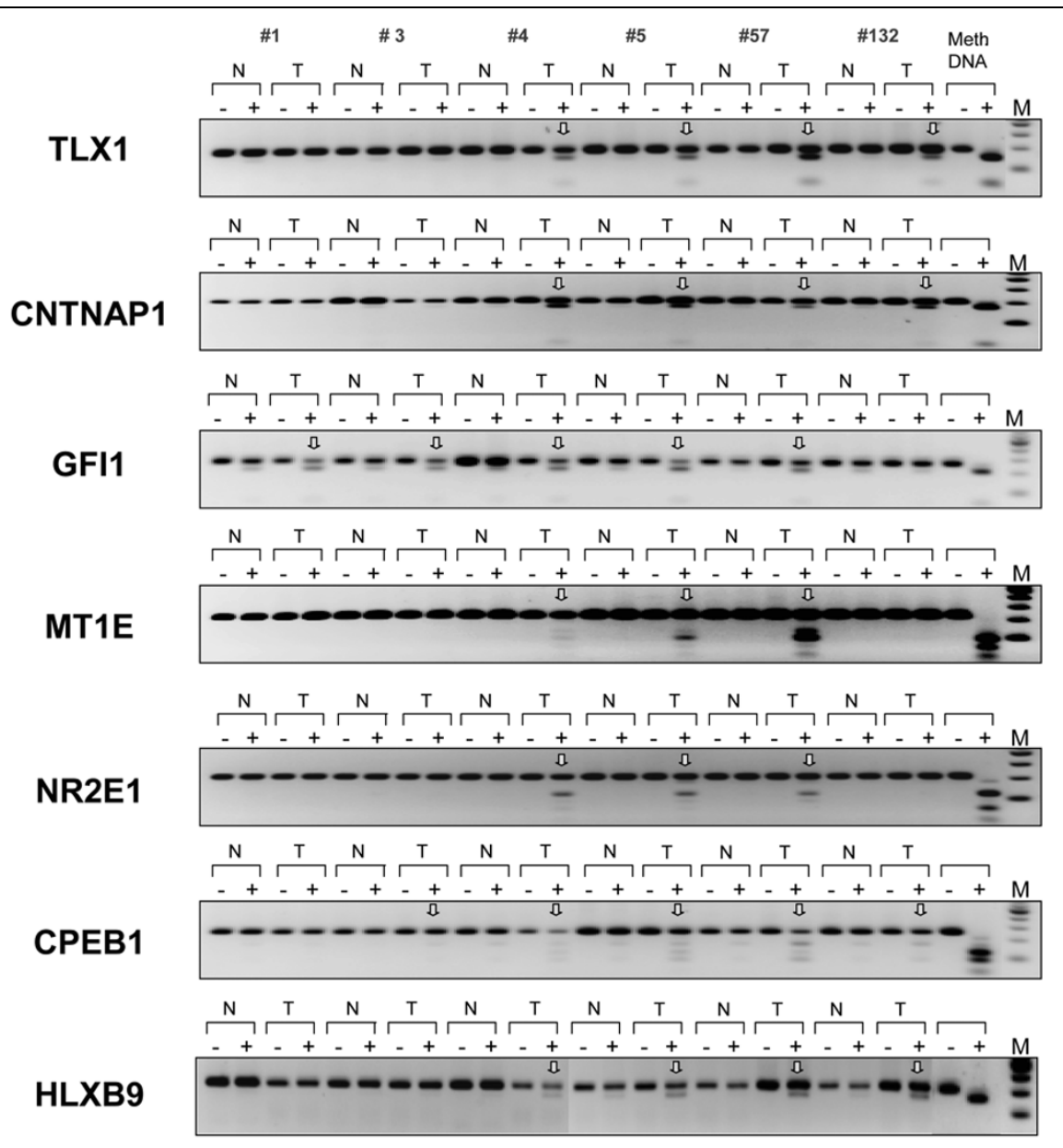

Verification of tumor-specific methylation of seven candidate target genes. These targets were identified by the MIRA-assisted microarray approach (target numbers 5, 7, 8, 29, 40, 42 and 54, corresponding to TLX1, CNTNAP1, GFI1, MT1E, NR2E1, CPEB1 and HLXB9, respectively; Table 1). Genomic DNA from ductal carcinomas in situ $(\mathrm{T})$ and matching normal breast tissues $(\mathrm{N})$ was treated with sodium bisulfite and the target $\mathrm{CpG}$ island sequences were amplified using gene-specific primers. Methylation was confirmed by a BstUl combined bisulfite restriction analysis assay, which produces digestion products when BstUI restriction sites are methylated and not converted by bisulfite. HeLa DNA was methylated in vitro with the Sssl methyltransferase and served as a positive control (Meth. DNA, Methylated HeLa DNA). Vertical white arrows indicate hypermethylated alleles in the target sequence. \pm , digestion was carried out with or without BstUl restriction enzyme; N/T, normal/tumor pairs. When matching normal tissue was not available, a DNA mixture derived from several normal breast tissues was used instead. M, DNA marker.

breast tumors (six DCIS and 15 stage I tumors, 52\%) (Figure 4, partial data and Table 3).

To assess the extent of $\mathrm{CpG}$ methylation within the $H O X B 13$, $H N F 1 B, H L X B 9$ and $C G I$ 7:48 target sequences, primary breast tumors were also subjected to bisulfite DNA sequencing together with their matching normal tissues (DCIS case number 57 and stage I case numbers $4 \mathrm{~b}$ and 233). As expected, there is an evident tendency towards increased methylation in tumor-derived samples; the occurrence of earlystage cancer-specific methylated $\mathrm{CpGs}$ is very significant $(P$ $<0.001$, Fisher's exact test) (Figure 6).

\section{Discussion}

DCIS is suspected to be a direct, although not obligate, precursor of invasive breast cancer, and aberrant DNA methyla- tion is believed to play a crucial role in breast tumorigenesis. Considering that epigenetic changes often become apparent in early phases of the disease, we speculated that the identification of DCIS-specific methylated biomarkers might be crucial to elucidate the molecular mechanisms underlying the initiation and development of breast cancer and to conceive effective strategies for early diagnosis.

To acquire valuable information into the epigenetic switches that may promote and/or contribute to the initial neoplastic events, we have analyzed the DNA methylation profile of DCIS, on a MIRA-based CpG island microarray platform. This novel and sensitive genome-wide screening approach has led to the identification of $108 \mathrm{CpG}$ islands that display aberrant levels of DNA methylation in early breast lesions. Of the $81 \mathrm{CpG}$ islands associated with known genes, only 37 map to pro- 


\section{CGI 7: 48}

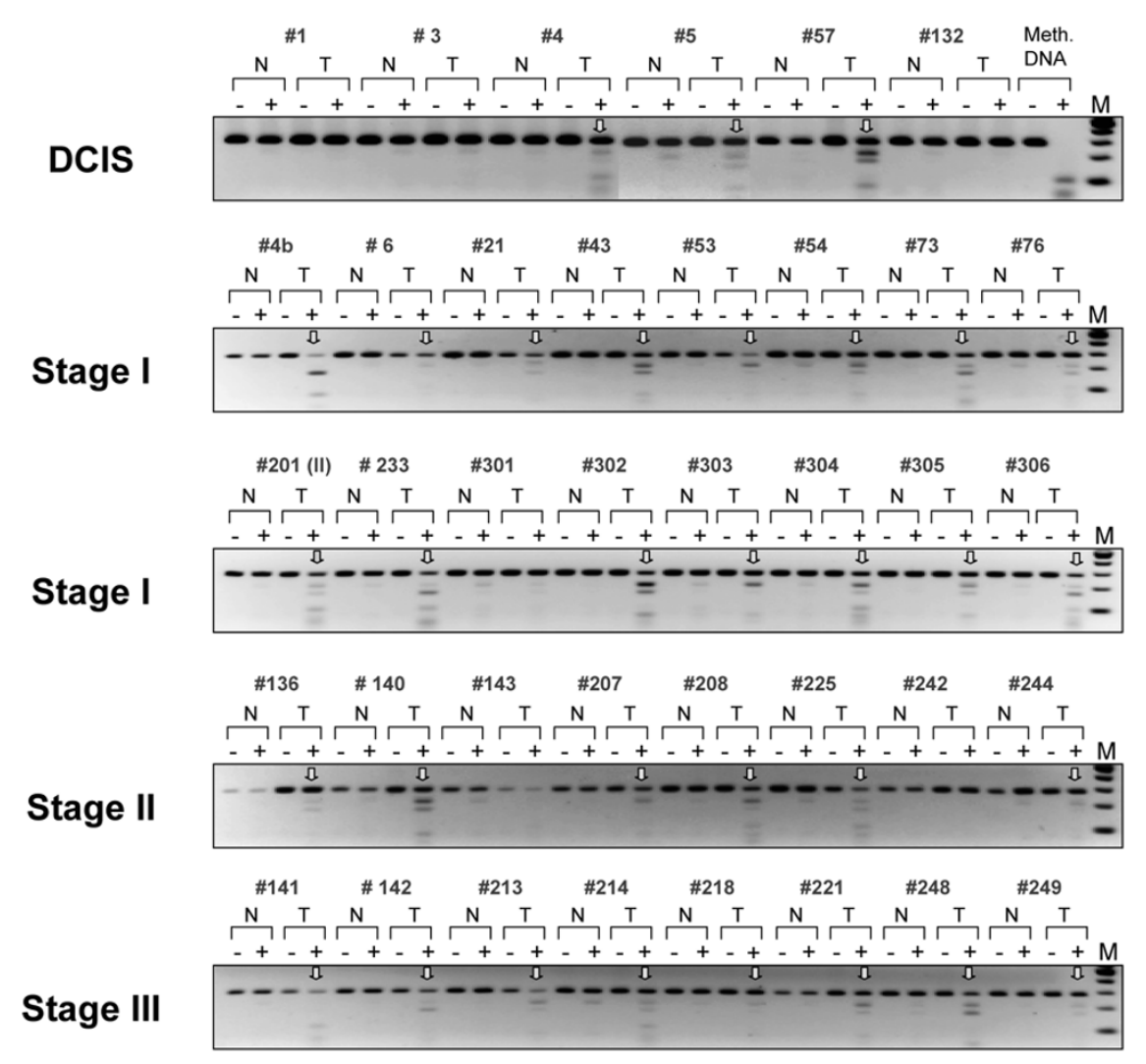

Methylation of an uncharacterized CpG island on chromosome 7. Six cases of ductal carcinoma in situ (DCIS) and 32 invasive breast tumors of different histological type and grade were analyzed for $\mathrm{CpG}$ methylation. The target $\mathrm{CpG}$ island (hit number 5, Table 2) was subjected to the BstUl combined bisulfite restriction analysis assay. N/T, normal/tumor pairs. Vertical arrows indicate tumor-specific methylation. Target number 201 is a stage II breast carcinoma. M, DNA marker; Meth. DNA, HeLa DNA methylated in vitro with Sssl methyltransferase, serving as a positive control.

moter regions or further upstream (46\%). In agreement with recently published data [40], more than one-half of the methylated $\mathrm{CpG}$ islands in normal genomes fall within the body of the gene or in downstream regions. The functional role of these intergenic and intragenic CpG-rich elements remains obscure, but it has been suggested that they may constitute short independent transcriptional units [40].

Several targets have been examined by conventional bisulfite methods and found to be differentially methylated in multiple breast tumors, in complete agreement with the MIRA results. Most importantly, these gene candidates display methylation frequencies ranging from $50 \%$ to $83 \%$ in DCIS and up to $93 \%$ in stage I breast cancer, depending on the target gene, and these candidates hold great promise, alone or in combination, for future diagnostic applications. We were also able to identify several genes, such as CDKN2A, PCDHGB6, and WT1 (Table 1) well known to be methylated and transcriptionally silent in breast cancer $[10,23]$. Many other 'conventional' methylation markers, however, were not represented in our data set. This apparent discrepancy with previous reports can be ascribed, in part, to the different conditions utilized in microarray data analysis to define thresholds; consequently, some genes may be classified as false negative simply because they fall below the statistical cutoff points. Digestion of genomic DNA, prior to the MIRA pull down, with the methylation-sensitive endonuclease $H$ hal can also be crucial in excluding those $\mathrm{CpG}$ islands that are not methylated at Hhal restriction sites (5'-GCGC), although they are methylated at surrounding CpGs within the target sequence. In addition, genes previously described as methylated in advanced-stage breast cancer may not be methylated in DCIS.

Surprisingly, most of the targets identified in the present study have never been linked to epigenetic errors during breast carcinogenesis and may shed new light into the molecular mechanisms underlying the insurgence of breast cancer. The employment of undissected breast tissue that fails to discern the epigenetic contribution of the single cell subtypes and the restricted number of DCIS used in the microarray analysis, 
Figure 4

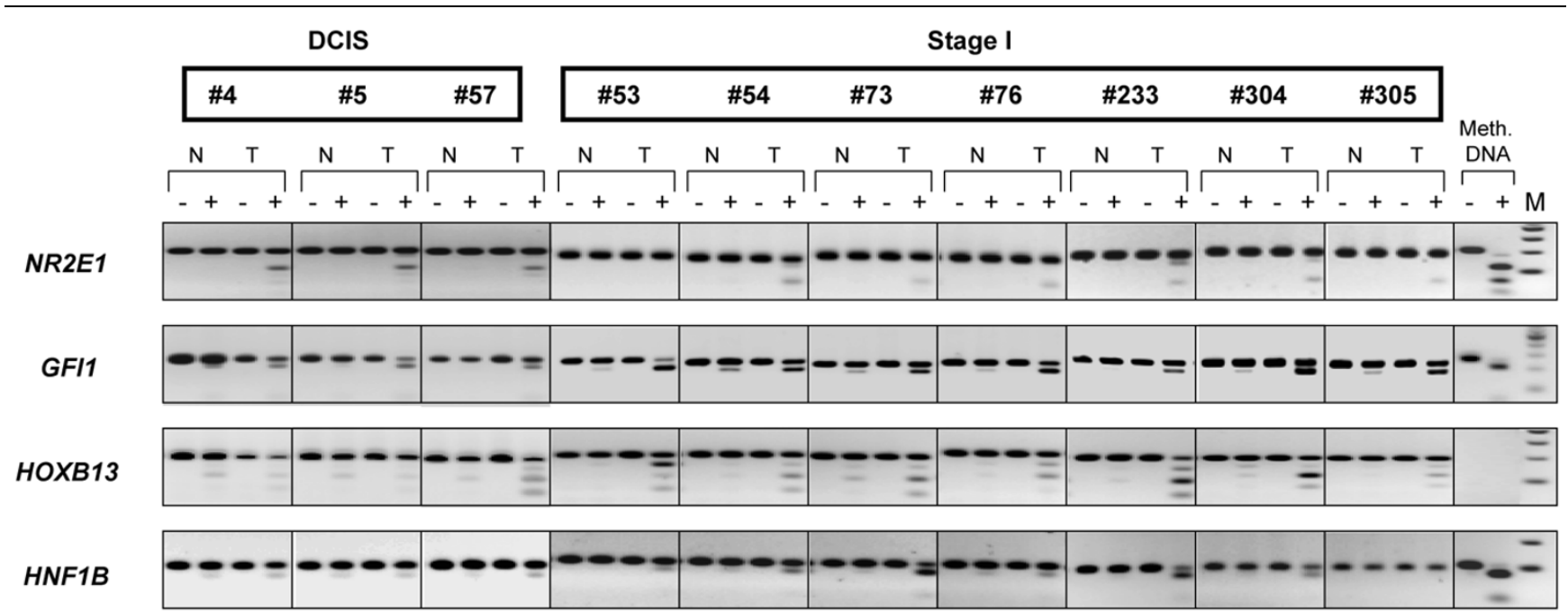

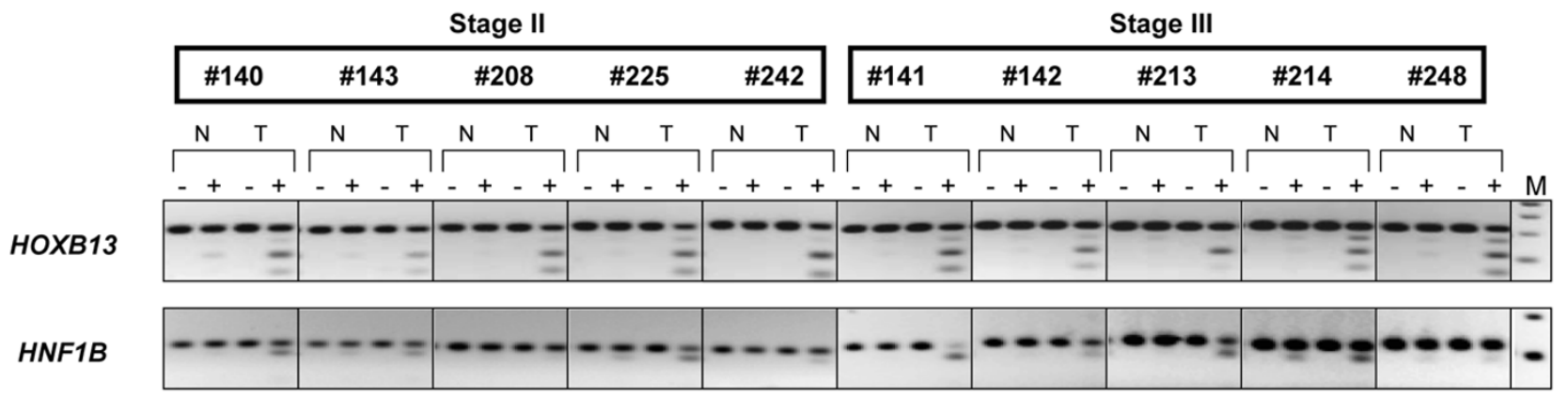

Combined bisulfite restriction analysis in ductal carcinoma in situ and more advanced primary breast tumors. The NRN1, GFI1, HOXB13, HNF1Bassociated $\mathrm{CpG}$ islands were analyzed by Combined bisulfite restriction analysis in ductal carcinoma in situ (DCIS) and more advanced breast carcinoma. Three representative DCIS, seven stage I tumors, five stage II tumors and five stage III breast tumors are shown. The total number of specimens analyzed per gene and the relative methylation frequencies are presented in Table 3. N/T, normal/tumor pairs; M, DNA marker; Meth. DNA, HeLa DNA methylated in vitro with Sssl methyltransferase, serving as a positive control.

however, may represent important limitations to this study and need to be kept in consideration.

Apart from the potential discovery of novel tumor suppressor genes and/or methylation biomarkers, relevant for a better comprehension and management of the disease, the present study has uncovered a broad epigenetic phenomenon that occurs at the onset of breast cancer development. Interestingly, we found that $32 \%$ of the total hypermethylated $\mathrm{CpG}$ islands (26 out of the annotated 81 hits) are associated with members of multiple homeobox gene subfamilies - a surprisingly high percentage considering that, so far, only $\sim 300$ homeobox genes have been identified in the human genome (roughly $1 \%$ of the presumed battery of protein-coding genes) [41]. CpG methylation of homeobox genes has been sporadically observed during breast tumorigenesis; that is, methylation of the HOXB13 gene [39] and members of the HOXA cluster $[42,43]$. The extent and the recurrence of this epigenetic event in mammary carcinoma, however, have never been emphasized until now. Robust and frequent methylation of homeobox genes is not restricted to breast cancer, and occurs at significant frequencies $(\sim 10 \%$ to $20 \%$ of all methylated genes) in early-stage lung carcinoma $[28,35]$ - suggesting a common epigenetic pathway involving the homeobox gene network. Yet, the diverse and nonidentical methylation spectra exhibited by DCIS and stage I lung cancer at homeobox geneassociated $\mathrm{CpG}$ islands cautions against the existence of a common epigenetic phenotype among different tumor types. This is not surprising since the pattern and function of the homeobox gene networks are exclusive for a particular tissue [44] and no specific expression and/or CpG-island methylation signatures across tumors have so far been reported.

We cannot deduce why homeobox genes become preferential targets of aberrant CpG methylation during breast tumorigenesis and whether this extensive methylation can shift their finely tuned homeostasis, thus triggering tumorigenesis, or is merely associated with the neoplastic event. The widespread and recurrent nature of this phenomenon, however, seems to suggest that a common mechanistic pathway may exist in can- 


\section{TLX1}

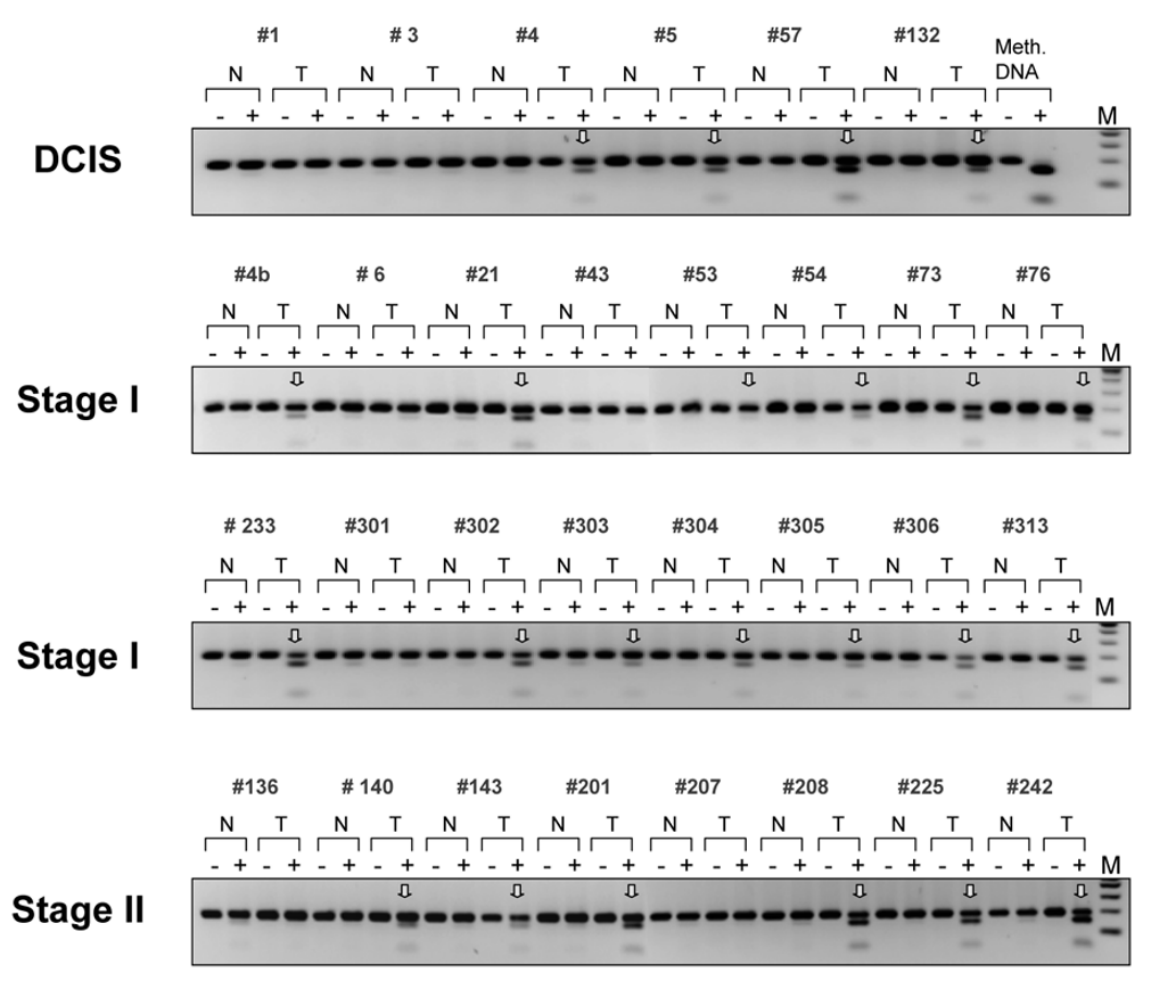

Methylation of the TLX1 gene in ductal carcinoma in situ and invasive primary breast tumors. Six cases of ductal carcinoma in situ (DCIS), 16 cases of stage I tumors, and eight cases of stage II tumors were analyzed. After sodium bisulfite treatment, the CpG island within the TLX1 gene was amplified with suitable primers and subjected to the BstUI combined bisulfite restriction analysis assay. Digested fragments on the gel are indicative of methylated BstUI restriction sites (5'-CGCG) within the CpG island. Vertical arrows indicate tumor-specific methylation in the target sequence. N/T, normal/tumor pairs; M, DNA marker; Meth. DNA, HeLa DNA methylated in vitro with Sssl methyltransferase, serving as a positive control.

cer cells, which promotes de novo methylation of these targets at the onset of tumor development.

Recent data have unraveled the role of Polycomb repressor complexes in targeting and modulating homeobox genes. At least six independent genome-wide studies have identified several common Polycomb targets in vertebrates and flies, most of which are represented by homeobox genes and other developmental transcription factors [45]. Interestingly, 43 out of the 81 annotated genes identified in the present study $(\sim 53 \%)$ and found to be hypermethylated in early-stage breast cancer overlap with known Polycomb targets, strongly supporting the PcG link [46]. Moreover, most of these DCIS-spe-

Table 3

Methylation frequencies of selected genes in ductal carcinoma in situ and invasive breast tumors

\begin{tabular}{lllll}
\hline & Ductal carcinoma in situ & Stage I tumors & Stage Il tumors & Stage III tumors \\
\hline TLX1 & $4 / 6(67 \%)$ & $13 / 16(81 \%)$ & $6 / 8(75 \%)$ & $7 / 9(78 \%)$ \\
CGI 7:48 & $3 / 6(50 \%)$ & $14 / 15(93 \%)$ & $8 / 9(89 \%)$ & $8 / 8(100 \%)$ \\
HOXB13 & $3 / 6(50 \%)$ & $13 / 15(87 \%)$ & $5 / 9(56 \%)$ & $5 / 8(100 \%)$ \\
HNF1B & $3 / 6(50 \%)$ & $11 / 15(73 \%)$ & $7 / 8(88 \%)$ & \\
GFI1 & $5 / 6(83 \%)$ & $9 / 12(75 \%)$ & & \\
NR2E1 & $3 / 6(50 \%)$ & $8 / 15(53 \%)$ & &
\end{tabular}


(a)

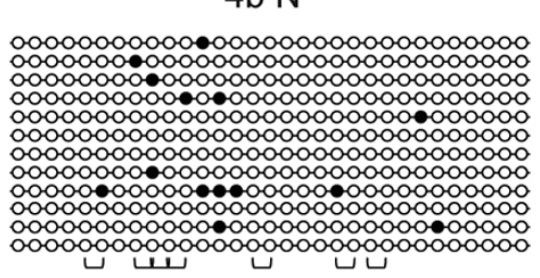

$57 \mathrm{~N}$

00000000000000000000000000000 \%000000000000000000000000

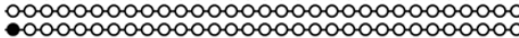
م-

(b)

\begin{tabular}{|c|}
\hline $4 \mathrm{~b} \mathrm{~N}$ \\
\hline 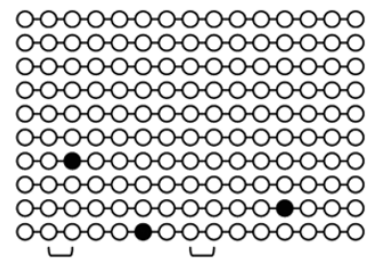 \\
\hline
\end{tabular}

$57 \mathrm{~N}$

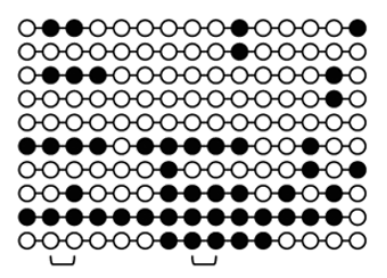

(c)

\begin{tabular}{|c|c|}
\hline $4 \mathrm{~b} \mathrm{~N}$ & $4 \mathrm{~b} \mathrm{~T}$ \\
\hline 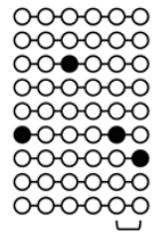 & \\
\hline $57 \mathrm{~N}$ & $57 \mathrm{~T}$ \\
\hline 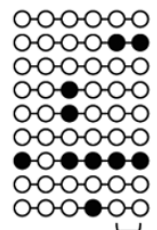 & 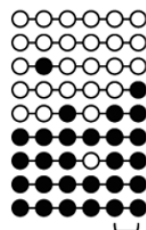 \\
\hline
\end{tabular}

$4 \mathrm{~b} T$

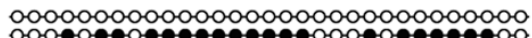

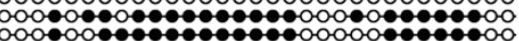
-

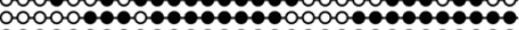
م-0. م-م,

\section{$57 \mathrm{~T}$}

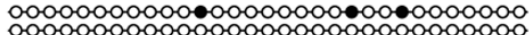
- - م-0- - - ڤ-

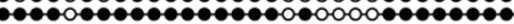
ப ᄂ

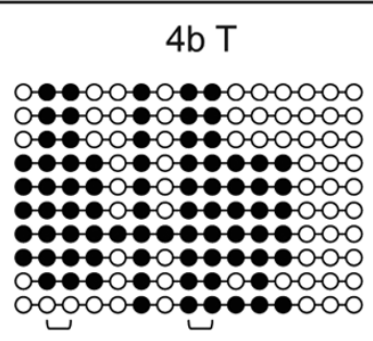

$57 \mathrm{~T}$

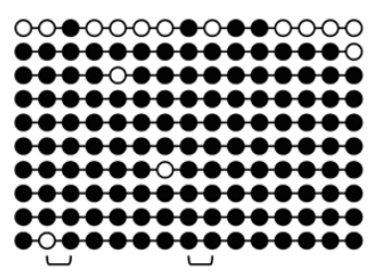

(d)

$233 \mathrm{~N}$

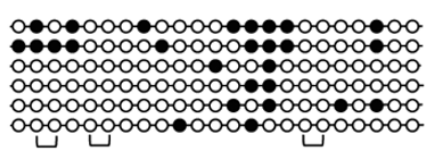

$233 \mathrm{~T}$

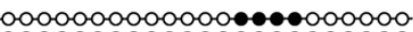

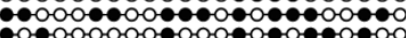
1.6-

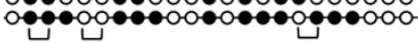

Bisulfite sequencing data. The extent of CpG methylation was determined for target sequences within (a) CGI 7:48, (b) HOXB13, (c) HNF1B, and (d) HLXB9 by sodium bisulfite sequencing. Primary breast tumors were subjected to bisulfite DNA sequencing together with their matching normal counterpart (ductal carcinoma in situ case number 57 and stage I, case numbers $4 \mathrm{~b}$ and 233). Sequencing results of several independent clones are shown. Black circles, methylated CpG dinucleotides. Open brackets indicate the location of the BstUl restriction sites in the target sequence. 
cific methylated $\mathrm{CpG}$ islands are embedded in regions other than promoters, consistent with the finding that the Polycomb repressive complex 2 subunit SUZ12 is distributed across large domains of developmental genes spanning from the promoter up to 2 to $35 \mathrm{~kb}$ into the gene [46]. SUZ12 is required for the histone methyltransferase activity and silencing function of the EED-EZH2 complex and is upregulated in different tumors, including breast tumors [47]. EZH2, another key Polycomb repressor complex 2 component, undergoes gene amplification in several tumor types [48] and is overexpressed in prostate cancer and breast cancer $[49,50]$. EZH2 physically interacts with all three DNA methyltransferases in mammalian cells, and has been suggested to play a crucial role in regulating de novo DNA methylation and its maintenance at target sequences [51].

Further support of this mechanistic connection between Polycomb silencing and tumor-associated DNA methylation comes from recent studies linking Polycomb occupancy of genes in noncancerous cells and tissues (including embryonic stem cells) with cancer-associated hypermethylation events $[28,35,52-55]$. Paradoxically, however, several homeobox genes are upregulated rather than downregulated in breast cancer and other tumor types, suggesting that several tiers of regulation, other than DNA methylation, may concur in determining homeobox misregulation. Several genome-wide PcG profiling studies have reported that $10 \%$ to $20 \%$ of the identified PcG targets are transcriptionally active $[46,56,57]$. Bracken and colleagues have suggested that, in undifferentiated cells, PcG complexes have the potential to target genes poised for silencing as well as target genes predisposed to activation [57]. The transition between alternative modes of PcG regulation may require additional signals upon differentiation (and likewise during tumorigenesis), which may include recruitment of additional transcriptional activators and/or competition with PcG antagonists, the tritorax group (trxG) proteins. These signals may all have a counteracting effect to the PcG-mediated gene repression [57].

In a similar scenario, it is conceivable that many of the homeobox gene-associated $\mathrm{CpG}$ islands that become methylated in DCIS might have already switched off their active transcriptional state in the normal breast epithelium or its progenitor cells. If that were the case, a hypothesis linking DNA methylation of homeobox gene CpG islands mechanistically to tumorigenesis would not be sustainable. Unfortunately, no RNA samples from DCIS were available to test the relationship between DNA methylation and gene expression.

\section{Conclusions}

Our results strongly suggest that homeobox genes and other developmental transcription factors become preferential targets of de novo methylation in DCIS. Aberrant methylation of these master regulators may play a crucial role in the insurgence and/or progression of breast cancer.

\section{Competing interests}

The authors declare that they have no competing interests.

\section{Authors' contributions}

ST designed the study, performed the experiments, interpreted the data, and wrote the manuscript. DLK performed the COBRA analysis. XW carried out the statistical analysis of the microarray data. YY contributed with the DCIS specimens and supervised the histological analysis. GPP designed the study, interpreted the data, and wrote the manuscript.

\section{Acknowledgements}

The authors would like to thank Dr Tibor Rauch and Maricela Covarrubias for help with MIRA and microarray processing, and thank Dr

Therese Ibrahim for help with tumor retrieval. They are also grateful to $\mathrm{Dr}$ Ahmad Besaratinia for critical reading of the manuscript and to $\mathrm{Dr}$ Ben $\mathrm{Paz}$ for helpful discussion. This work was supported by NIH grants to GPP (CA084469 and CA128495).

\section{References}

1. Althuis MD, Dozier JM, Anderson WF, Devesa SS, Brinton LA Global trends in breast cancer incidence and mortality 19731997. Int J Epidemiol 2005, 34:405-412.

2. Ting $\mathrm{AH}$, McGarvey KM, Baylin SB: The cancer epigenome components and functional correlates. Genes Dev 2006, 20:3215-3231.

3. Baylin SB, Esteller M, Rountree MR, Bachman KE, Schuebel K, Herman JG: Aberrant patterns of DNA methylation, chromatin formation and gene expression in cancer. Hum Mol Genet 2001, 10:687-692.

4. Herman JG, Baylin SB: Gene silencing in cancer in association with promoter hypermethylation. N Engl J Med 2003, 349:2042-2054.

5. Esteller M: Epigenetic gene silencing in cancer: the DNA hypermethylome. Hum Mol Genet 2007, 16(Spec No 1):R50-R59.

6. Yang X, Yan L, Davidson NE: DNA methylation in breast cancer. Endocr Relat Cancer 2001, 8:115-127.

7. Widschwendter $M$, Jones PA: DNA methylation and breast carcinogenesis. Oncogene 2002, 21:5462-5482.

8. Szyf M, Pakneshan P, Rabbani SA: DNA methylation and breast cancer. Biochem Pharmacol 2004, 68:1187-1197.

9. Li S, Rong M, lacopetta B: DNA hypermethylation in breast cancer and its association with clinicopathological features. Cancer Lett 2006, 237:272-280.

10. Agrawal A, Murphy RF, Agrawal DK: DNA methylation in breast and colorectal cancers. Mod Pathol 2007, 20:711-721.

11. Krassenstein R, Sauter E, Dulaimi E, Battagli $C$, Ehya $H$, KleinSzanto A, Cairns P: Detection of breast cancer in nipple aspirate fluid by $\mathrm{CpG}$ island hypermethylation. Clin Cancer Res 2004, 10(1 Pt 1):28-32.

12. Lehmann $U$, Langer F, Feist $H$, Glockner $S$, Hasemeier B, Kreipe $\mathrm{H}$ : Quantitative assessment of promoter hypermethylation during breast cancer development. Am J Pathol 2002, 160:605-612.

13. Yan PS, Venkataramu C, Ibrahim A, Liu JC, Shen RZ, Diaz NM, Centeno B, Weber F, Leu YW, Shapiro CL, Eng C, Yeatman TJ, Huang TH: Mapping geographic zones of cancer risk with epigenetic biomarkers in normal breast tissue. Clin Cancer Res 2006, 12:6626-6636.

14. Cheng AS, Culhane AC, Chan MW, Venkataramu CR, Ehrich M, Nasir A, Rodriguez BA, Liu J, Yan PS, Quackenbush J, Nephew KP, Yeatman TJ, Huang TH: Epithelial progeny of estrogen-exposed breast progenitor cells display a cancer-like methylome. Cancer Res 2008, 68:1786-1796.

15. Fackler MJ, McVeigh M, Evron E, Garrett E, Mehrotra J, Polyak K, Sukumar S, Argani P: DNA methylation of RASSF1A, HIN-1, RAR-beta, cyclin $\mathrm{D}_{2}$ and Twist in in situ and invasive lobular breast carcinoma. Int J Cancer 2003, 107:970-975. 
16. Lewis CM, Cler LR, Bu DW, Zochbauer-Muller S, Milchgrub S, Naftalis EZ, Leitch AM, Minna JD, Euhus DM: Promoter hypermethylation in benign breast epithelium in relation to predicted breast cancer risk. Clin Cancer Res 2005, 11:166-172.

17. Shinozaki M, Hoon DS, Giuliano AE, Hansen NM, Wang HJ, Turner R, Taback B: Distinct hypermethylation profile of primary breast cancer is associated with sentinel lymph node metastasis. Clin Cancer Res 2005, 11:2156-2162.

18. Fackler MJ, Malone K, Zhang Z, Schilling E, Garrett-Mayer E, SwiftScanlan T, Lange J, Nayar R, Davidson NE, Khan SA, Sukumar S: Quantitative multiplex methylation-specific PCR analysis doubles detection of tumor cells in breast ductal fluid. Clin Cancer Res 2006, 12(11 Pt 1):3306-3310.

19. Lee JS, Fackler MJ, Teo WW, Lee JH, Choi C, Park MH, Yoon JH, Zhang Z, Argani P, Sukumar S: Quantitative promoter hypermethylation profiles of ductal carcinoma in situ in north american and korean women: potential applications for diagnosis. Cancer Biol Ther 2008, 7:1398-1406.

20. Melnikov AA, Scholtens DM, Wiley EL, Khan SA, Levenson VV: Array-based multiplex analysis of DNA methylation in breast cancer tissues. J Mol Diagn 2008, 10:93-101.

21. Yan PS, Chen CM, Shi H, Rahmatpanah F, Wei SH, Caldwell CW, Huang TH: Dissecting complex epigenetic alterations in breast cancer using CpG island microarrays. Cancer Res 2001, 61:8375-8380.

22. Chen $\mathrm{CM}$, Chen $\mathrm{HL}$, Hsiau $\mathrm{TH}$, Hsiau $\mathrm{AH}$, Shi H, Brock GJ, Wei $\mathrm{SH}$, Caldwell CW, Yan PS, Huang TH: Methylation target array for rapid analysis of $\mathrm{CpG}$ island hypermethylation in multiple tissue genomes. Am J Patho/ 2003, 163:37-45.

23. Miyamoto K, Fukutomi T, Akashi-Tanaka S, Hasegawa T, Asahara T, Sugimura T, Ushijima T: Identification of 20 genes aberrantly methylated in human breast cancers. Int J Cancer 2005, 116:407-414

24. Piotrowski $A$, Benetkiewicz $M$, Menzel $U$, de Ståhl TD, Mantripragada K, Grigelionis G, Buckley PG, Jankowski M, Hoffman J, Baca D, Srutek E, Laskowski R, Zegarski W, Dumanski JP: Microarraybased survey of $\mathrm{CpG}$ islands identifies concurrent hyper- and hypomethylation patterns in tissues derived from patients with breast cancer. Genes Chromosomes Cancer 2006, 45:656-667.

25. Ordway JM, Budiman MA, Korshunova Y, Maloney RK, Bedell JA, Citek RW, Bacher B, Peterson S, Rohlfing T, Hall J, Brown R, Lakey N, Doerge RW, Martienssen RA, Leon J, McPherson JD, Jeddeloh JA: Identification of novel high-frequency DNA methylation changes in breast cancer. PLOS ONE 2007, 2:e1314.

26. Hu M, Yao J, Carroll DK, Weremowicz $S$, Chen $\mathrm{H}$, Carrasco $D$, Richardson A, Violette S, Nikolskaya T, Nikolsky Y, Bauerlein EL, Hahn WC, Gelman RS, Allred C, Bissell MJ, Schnitt S, Polyak K: Regulation of in situ to invasive breast carcinoma transition. Cancer Cell 2008, 13:394-406.

27. Rauch T, Pfeifer GP: Methylated-CpG island recovery assay: a new technique for the rapid detection of methylated-CpG islands in cancer. Lab lnvest 2005, 85:1172-1180.

28. Rauch $\mathrm{T}, \mathrm{LiH}, \mathrm{Wu}$ X, Pfeifer GP: MIRA-assisted microarray analysis, a new technology for the determination of DNA methylation patterns, identifies frequent methylation of homeodomain-containing genes in lung cancer cells. Cancer Res 2006, 66:7939-7947

29. Coletta RD, Jedlicka P, Gutierrez-Hartmann A, Ford HL: Transcriptional control of the cell cycle in mammary gland development and tumorigenesis. J Mammary Gland Biol Neoplasia 2004, 9:39-53.

30. Lewis MT: Homeobox genes in mammary gland development and neoplasia. Breast Cancer Res 2000, 2:158-169.

31. Chen $\mathrm{H}$, Sukumar S: Role of homeobox genes in normal mammary gland development and breast tumorigenesis. J Mammary Gland Biol Neoplasia 2003, 8:159-175.

32. Greene FL, Page DL, Balch CM, Fleming ID, Morrow M: AJCC Cancer Staging Manual 6th edition. Springer-Verlag New York, LLC; 2002

33. Rauch TA, Zhong X, Wu X, Wang M, Kernstine KH, Wang Z, Riggs $A D$, Pfeifer GP: High-resolution mapping of DNA hypermethylation and hypomethylation in lung cancer. Proc Natl Acad Sci USA 2008, 105:252-257.

34. Xiong Z, Laird PW: COBRA: a sensitive and quantitative DNA methylation assay. Nucleic Acids Res 1997, 25:2532-2534.
35. Rauch T, Wang Z, Zhang X, Zhong X, Wu X, Lau SK, Kernstine KH, Riggs AD, Pfeifer GP: Homeobox gene methylation in lung cancer studied by genome-wide analysis with a microarray-based methylated CpG island recovery assay. Proc Natl Acad Sci USA 2007, 104:5527-5532.

36. Abate-Shen C: Deregulated homeobox gene expression in cancer: cause or consequence? Nat Rev Cancer 2002, 2:777-785.

37. Bloushtain-Qimron N, Yao J, Snyder EL, Shipitsin M, Campbell LL, Mani SA, Hu M, Chen H, Ustyansky V, Antosiewicz JE, Argani P, Halushka MK, Thomson JA, Pharoah P, Porgador A, Sukumar S, Parsons R, Richardson AL, Stampfer MR, Gelman RS, Nikolskaya T, Nikolsky Y, Polyak K: Cell type-specific DNA methylation patterns in the human breast. Proc Natl Acad Sci USA 2008, 105:14076-14081.

38. Euhus DM, Bu D, Milchgrub S, Xie XJ, Bian A, Leitch AM, Lewis $\mathrm{CM}$ : DNA methylation in benign breast epithelium in relation to age and breast cancer risk. Cancer Epidemiol Biomarkers Prev 2008, 17:1051-1059.

39. Rodriguez BA, Cheng AS, Yan PS, Potter D, Agosto-Perez FJ, Shapiro CL, Huang TH: Epigenetic repression of the estrogenregulated Homeobox B13 gene in breast cancer. Carcinogenesis 2008, 29:1459-1465.

40. Illingworth R, Kerr A, Desousa D, Jørgensen H, Ellis P, Stalker J, Jackson D, Clee C, Plumb R, Rogers J, Humphray S, Cox T, Langford C, Bird A: A novel CpG island set identifies tissue-specific methylation at developmental gene loci. PLOS Biol 2008, 6:e22.

41. Holland PW, Booth HA, Bruford EA: Classification and nomenclature of all human homeobox genes. BMC Biol 2007, 5:47.

42. Raman V, Martensen SA, Reisman D, Evron E, Odenwald WF, Jaffee E, Marks J, Sukumar S: Compromised HOXA5 function can limit p53 expression in human breast tumours. Nature 2000 405:974-978.

43. Novak $\mathrm{P}$, Jensen $T$, Oshiro MM, Wozniak RJ, Nouzova M, Watts GS, Klimecki WT, Kim C, Futscher BW: Epigenetic inactivation of the HOXA gene cluster in breast cancer. Cancer Res 2006, 66:10664-10670.

44. Chen H, Sukumar S: HOX genes: emerging stars in cancer. Cancer Biol Ther 2003, 2:524-525.

45. Ringrose L: Polycomb comes of age: genome-wide profiling of target sites. Curr Opin Cell Biol 2007, 19:290-297.

46. Lee TI, Jenner RG, Boyer LA, Guenther MG, Levine SS, Kumar RM Chevalier B, Johnstone SE, Cole MF, Isono K, Koseki H, Fuchikami $\mathrm{T}$, Abe K, Murray HL, Zucker JP, Yuan B, Bell GW, Herbolsheimer E, Hannett NM, Sun K, Odom DT, Otte AP, Volkert TL, Bartel DP, Melton DA, Gifford DK, Jaenisch R, Young RA: Control of developmental regulators by Polycomb in human embryonic stem cells. Cell 2006, 125:301-313.

47. Kirmizis A, Bartley SM, Farnham PJ: Identification of the polycomb group protein $\mathrm{SU}(\mathrm{Z}) 12$ as a potential molecular target for human cancer therapy. Mol Cancer Ther 2003, 2:113-121.

48. Bracken AP, Pasini D, Capra M, Prosperini E, Colli E, Helin K: EZH2 is downstream of the pRB-E2F pathway, essential for proliferation and amplified in cancer. EMBO J 2003, 22:5323-5335.

49. Raaphorst FM: Deregulated expression of Polycomb-group oncogenes in human malignant lymphomas and epithelial tumors. Hum Mol Genet 2005, 14(Spec No 1):R93-R100.

50. Ding L, Kleer CG: Enhancer of Zeste 2 as a marker of preneoplastic progression in the breast. Cancer Res 2006, 66:9352-9355.

51. Viré E, Brenner C, Deplus R, Blanchon L, Fraga M, Didelot C, Morey L, Van Eynde A, Bernard D, Vanderwinden JM, Bollen M, Esteller M, Di Croce L, de Launoit Y, Fuks F: The Polycomb group protein EZH2 directly controls DNA methylation. Nature 2006, 439:871-874.

52. Ohm JE, McGarvey KM, Yu X, Cheng L, Schuebel KE, Cope L Mohammad HP, Chen W, Daniel VC, Yu W, Berman DM, Jenuwein T, Pruitt K, Sharkis SJ, Watkins DN, Herman JG, Baylin SB: A stem cell-like chromatin pattern may predispose tumor suppressor genes to DNA hypermethylation and heritable silencing. Nat Genet 2007, 39:237-242.

53. Schlesinger Y, Straussman R, Keshet I, Farkash S, Hecht M, Zimmerman J, Eden E, Yakhini Z, Ben-Shushan E, Reubinoff BE, Bergman $\mathrm{Y}$, Simon I, Cedar H: Polycomb-mediated methylation on 
Lys27 of histone $\mathrm{H} 3$ pre-marks genes for de novo methylation in cancer. Nat Genet 2007, 39:232-236.

54. Widschwendter M, Fiegl H, Egle D, Mueller-Holzner E, Spizzo G, Marth C, Weisenberger DJ, Campan M, Young J, Jacobs I, Laird PW: Epigenetic stem cell signature in cancer. Nat Genet 2007, 39:157-158.

55. Hahn MA, Hahn T, Lee DH, Esworthy RS, Kim BW, Riggs AD, Chu FF, Pfeifer GP: Methylation of polycomb target genes in intestinal cancer is mediated by inflammation. Cancer Res 2008, 68:10280-10289.

56. Boyer LA, Plath K, Zeitlinger J, Brambrink T, Medeiros LA, Lee TI, Levine SS, Wernig M, Tajonar A, Ray MK, Bell GW, Otte AP, Vidal M, Gifford DK, Young RA, Jaenisch R: Polycomb complexes repress developmental regulators in murine embryonic stem cells. Nature 2006, 441:349-353.

57. Bracken AP, Dietrich N, Pasini D, Hansen KH, Helin K: Genomewide mapping of Polycomb target genes unravels their roles in cell fate transitions. Genes Dev 2006, 20:1123-1136. 